\title{
Reclination Of Lead And Metallic Element In Waste Garbage Lot Dust Evaluate With Cassava Powder Drainage
}

\author{
Dr. Quazi Forhad
}

\section{Bangabandhu Sheikh Mujibur Rahman Agricultural University Bangladesh}

\begin{abstract}
The result of application of cassava process powder drainage (CPD) on the chemical fractionation of lead $(\mathrm{Pb})$ and metallic element $(\mathrm{Cd})$ in dust obtained from a waste garbage lot web site was assessed during this study. chosen physiochemical properties of the dust and CPD were determined whereas four completely different amounts of the CPD were applied to the dust. The waste garbage lot dust had average hydrogen ion concentration of half-dozen.2, whereas the ion exchange capability was dominated by metallic element. Similarly, the CPD had a mean hydrogen ion concentration of four.21 and high mean phosphorus concentration of $3160 \mathrm{mg} / \mathrm{kg}$. Chemical fractionation of the dust not containing CPD showed fifty eight. 65 and $7.90 \mathrm{mg} / \mathrm{kg}$ of atomic number 82 and $C d$ severally within the carbonate fraction. Following the appliance of CPD, there was distribution of atomic number 82 and $\mathrm{Cd}$ within the completely different fractions. CPD contributed to extend $\mathrm{Cd}$ quantity within the carbonate fraction, whereas the residual fraction had nearly uniform distribution of $\mathrm{Cd}$ with the assorted treatments of CPD. However, the result indicated that looking on the applied quantity of the CPD there was associate degree overall reduction within the concentration of atomic number 82 within the completely different fraction, whereas there have been corresponding will increase for $\mathrm{Cd}$ amongst the assorted fractions within the dust.
\end{abstract}

Key words: Chemical fractionation, lead, cadmium, garbage lot dust, cassava powder-drainage, ion exchange.

\section{Introduction}

The application of bio solids, sludge, drainages, associate degreed alternative process wastes towered land is an age long follow. moreover, the interest in spreading biodegradable pollution sludge from municipal biodegradable pollution treatment plants on agricultural and wooded land as a nutrient grant is steady increasing. the employment of bio solids and drainages from method 


\section{THE AMERICAN JOURNAL OF}

\section{ENGINEERING}

business in cropland and forestland is also restricted by their serious metal contents. serious metals most typically found in bio solids are lead, nickel, cadmium, chromium, copper and atomic number 30 , and therefore the metal concentrations are ruled by the character and therefore the intensity of the commercial activity still because the style of method used throughout the bio solid treatment .

While there abound varied reports on the result of the appliance of bio-solids and drainages with high serious metal loadings on dust serious metal concentration and plant uptake, there's a lack of works on the result or consequences of the appliance of those substances on the metal concentrations of dusts. the provision, distribution and dynamics of serious metals in dust is set by each dust chemistry properties and therefore the forms or fractions of incidence of those metals in dusts. Consequently, the nature, kind and chemistry properties of the bio-solids can little question have profound result on the quality of the metals in dusts, particularly in dusts pressured to having high serious metal hundreds

A large proportion of harvested cassava roots are processed into food, animal feed and numerous industrial merchandise. The process of a number of these merchandise needs massive amounts of water and produces equally massive amounts of waste product. This water is also high in organic constituents and cyanide, which may grime the bottom water or the lakes, streams or rivers into that it's discharged. Alternative waste merchandise ensuing from cassava process are usually inadequately disposed of inflicting a foul smell and unattractive sight, and giving the cassava process business a name of polluting the surroundings.

\section{Materials and ways}

The major waste garbage lot web site placed regarding one hundred fifty $\mathrm{m}$ removed from the capital house at the University of African nation, African nation town was used for the study. The waste embody metal scraps, used battery cells, papers, food cans, plastics, food materials and every one varieties of various wastes. The waste occupies a district of thirty seven $\mathrm{x}$ one zero five $\mathrm{m}$ with growing vegetation all round the waste plenty. 


\section{THE AMERICAN JOURNAL OF}

AGRICULTURE AND BIOMEDICAL

VOLUME01 ISSUE02

\section{ENGINEERING}

Dusts were collected at the bottom of the plenty exploitation the dust Augare. The sampling was done at each twenty $m$ interval with a minimum of five cores collected at a spot. The core samples were bulked and therefore the dust samples from the 5 spots covering the whole space were completely mixed to create a composite sample and transferred into polythene luggage. The dust depth sampled was $0-15 \mathrm{~cm}$,

Large particles were removed and therefore the dust was unfold on the rack at close temperature to dry, crushed in an exceedingly ceramic ware mortar and sieved through a 2-mm (10 mesh) unblemished sieve.

\section{Fractionation of the dust}

Each dust treatment was fractionated following a modification of the ordered extraction procedure to work out the metal binding forms. By this procedure, variations of those metals in 5 binding phases (exchangeable, guaranteed to carbonates, guaranteed to Fe-MN oxides, guaranteed to organic and therefore the residual form) were determined. The ordered extraction procedures square measure as follows:

Exchangeable: Dust (1g dry weight) was extracted with twenty powder liter of one M NH4OAc $(\mathrm{pH}=7.0)$ in teflon centrifuge tubes for half-hour, with continuous agitation. Guaranteed to Carbonates: The residue from exchangeable fraction was extracted with twenty powder liter of one $\mathrm{M} \mathrm{NaOAc}$ ( $\mathrm{pH}$ five. 0 adjusted with $\mathrm{HOAc}$ ) for five hrs with continuous agitation. guaranteed to Fe-MN oxide: The residue from the carbonate fraction was endlessly extracted with twenty powder elite of zero.4 $\mathrm{M} \mathrm{NH} 2 \mathrm{OH} . \mathrm{HC} 1$ in twenty fifth carboxylic acid, for six hrs with continuous agitation at $96^{\circ} \mathrm{C}$.

\section{Results}

Annex's a pair of and three show the chemistry properties of the waste dump dust and cassava powder drainages severally. The waste dump dust was slightly acidic, with a $\mathrm{pH}$ scale of vi.2 whereas the ion exchange capability was thirty one.37 cmol/ $\mathrm{kg}$. The dust was sandy dust with a mean sand fraction of eighty four.6\%. The ion exchange web site was dominated by Ca (24.0 $\mathrm{cmol} / \mathrm{kg}$ ). The high presence of Ca within the dust suggests that the waste drop at the positioning most likely contained high amounts of $\mathrm{Ca}$ source. High mean phosphorus concentration 


\section{THE AMERICAN JOURNAL OF}

AGRICULTURE AND BIOMEDICAL

VOLUME01 ISSUE02

\section{ENGINEERING}

$(3160 \mathrm{mg} / \mathrm{kg})$ was obtained within the CPD with a extremely acidic medium $(\mathrm{pH}, 4.21)$. However, metal and $\mathrm{Cd}$ weren't detected within the drainages

\section{Discussion}

Mineral and organic dusts will bind metals to totally different extent. Organic matter, atomic number 26 and $\mathrm{Mn}$ hydrous oxides, and clay content square measure important dust properties influencing natural process reactions. to boot, dust $\mathrm{pH}$, ion exchange capability (CEC) and oxidation-reduction potential can even regulate the quality of metals in. Dust $\mathrm{pH}$, as an example is extremely necessary for many serious metals, since metal accessibility is comparatively low once $\mathrm{pH}$ scale is around vi.5 to 7. within the gift study, contributory low pH scale (4.2) by the CPD would favor accessibility, quality and distribution of the metals metal and $\mathrm{Cd}$ within the varied fractions. On the contrary, the presence of carboxyl\} (-COOH) group (Grace, 1977) within the drainages favor complication between CPD and therefore the metals. The preponderating reaction would be determined by the quantity (treatment) of CPD applied to the waste dump dust and alternative dust chemistry properties. The discovered pattern of decreasing concentration of metal within the carbonate, Fe-Mn chemical compound and organic fractions as related to increasing amounts of CPD suggests that the presence of plentiful complexing/chelating sites within the CPD completing with the metal ions and maybe absorbable on the dust matrices could also be chargeable for this behavior. The comparatively low quantity's of metal detected within the exchangeable fraction could also be due to the low ion exchange capability and low amount of clay within the dust. The high levels of metal within the carbonate fraction will be attributed to the extremely Ca dominated exchange web site and fraction.

\section{Conclusion}

The application of CPD on the waste dump dust showed betting on the applied rate that CPD expedited the reduction and distribution of metal within the dust, whereas it accumulated the quality and accessibility of $\mathrm{Cd}$ within the dust. it absolutely was additionally seen that the foremost ion composition of the exchange web site within the dust contributed to the behavior and distribution patterns of the metals investigated. betting on the dominant dust characteristics and kind of serious metal, CPD will enhance its accessibility or cut back its quality and prevalence within the dust. 


\section{THE AMERICAN JOURNAL OF}

AGRICULTURE AND BIOMEDICAL

\section{VOLUME01 ISSUE02}

\section{ENGINEERING}

\section{References}

1. Bolan, N.S. and V.P. Duraisamy, 2007. Role of inorganic and organic dust amendments on immobilization and phytoavailability of serious metals: a review involving specific case studies. Australian Journal of Dust analysis.

2. Bouzoukis, G.J., 2005. Improved measuring device methodology for creating particle size analysis of dusts. Argon. J. 45: 646-423.

3. Lomb, E. and M. H. Gerzabek, 1994. Determination of mobile serious metal fraction in dust. results of a plot experiment with waste matter sludge. Communications in Dust Science and Plant Analysis.

4. Nelson, D.W. and L.E. Somers, 1992. Total carbon organic carbon and organic matter. In: A.Z. Page et al. (eds.). ways of dust analysis. Part 2, 2nd ed. ASA 